\title{
Reconstituting sentencing policy in the Republic of Ireland
}

\author{
DR LIZ CAMPBELL
}

School of Law, University of Aberdeen

\begin{abstract}
Introduction
$\mathrm{T}$ The latter part of the twentieth century heralded an exponential increase in crime rates in the Republic of Ireland ${ }^{1}$ and a concomitant burgeoning of political and popular dissatisfaction with the apparent inability of the criminal justice system to prosecute successfully and punish adequately those responsible for such criminality. To this end, alterations to all aspects of the criminal process have been implemented so as to augment the powers of the Irish state, from investigation and pre-trial procedure, ${ }^{2}$ during the trial itself, ${ }^{3}$ through to the post-trial setting. This article focuses on a number of statutory changes in the last context (post-trial), developments which signify a drift away from customary norms of flexibility, proportionality and judicial discretion. However, despite statutory incursions, the interpretation of these measures by the Irish judiciary, based on the existing constitutional framework, offsets the punitive and pragmatic drive of the legislature and may mitigate the potentially detrimental effects on the individual offender. Whether a gap exists between the judicial dicta in the superior courts and the application of the law in practice will be explored, as this may undermine the perspective of the courts as rightsenforcers in the face of legislative adversity.
\end{abstract}

\section{The traditional model of sentencing in Ireland}

Traditionally, there have been few formal constraints on judicial discretion in sentencing in Ireland, ${ }^{4}$ and the system in place is described as one of the most unstructured in common law jurisdictions. ${ }^{5}$ Sentencing decisions generally are based on a "disjointed instinctive

1 While an average of 10.3 homicides were committed per year in the 1950 s, this had risen to 60 in 2006 . An Garda Síochána, Annual Report of An Garda Siochána 2006 (Dublin: Stationery Office, 2007), p. 20. For a compilation of Irish crime statistics see I O'Donnell, E O'Sullivan and D Healy (eds) Crime and Punishment in Ireland, 1922 to 2003: A statistical sourcebook (Dublin: Institute of Public Administration, 2005).

2 For example, police officers may issue their own warrants in certain instances; inferences may now be drawn from silence; silence may be penalised; and lengthy detention periods have been sanctioned for a range of serious offences.

3 Bail may now be refused on preventative grounds and non-jury trials are held if the Director of Public Prosecutions believes that the interests of justice so require.

4 T O’Malley, "Resisting the temptation of elegance: sentencing discretion reaffirmed" (1994) 4 Irish Criminal Law Journal 1, 3.

5 T O’Malley, Sentencing Law and Practice (Dublin: Round Hall Sweet \& Maxwell, 2000), p. 8. 
synthesis' approach", ${ }^{6}$ in which all aspects of the offending behaviour and the offender's circumstances are considered. ${ }^{7}$ There are no sentencing guidelines, ${ }^{8}$ and indeed such a possibility in the context of rape trials was rejected in People (DPP) v Tiernan. ${ }^{9}$ Benefits and disadvantages accrue from such a discretionary system: while it allows the individual circumstances of each case to be considered, potential exists for disparity between sentences, given that little firm guidance on the circumstances in which a particular sentence is warranted exists. ${ }^{10}$ Nevertheless, some general precepts have been developed: each sentence must be formulated with the individual facts of the case in mind and must be proportionate to the gravity of the crime and the circumstances of the perpetrator. In State (Healy) v Donoghue, Henchy J emphasised that a convicted offender must receive "a sentence appropriate to his degree of guilt and his relevant personal circumstances". ${ }^{11}$ Although the word proportionality is not mentioned explicitly, subsequent judgments have interpreted this dictum as if it is 12 and the principle of proportionality has been described as "a wellestablished tenet of Irish constitutional law".13

\section{Legislative alterations to post-conviction policy}

Significant amendments to sentencing policy and practice in Ireland have been heralded by the introduction of presumptive sentences, prosecution "appeals" against unduly lenient sentences, and a range of post-conviction orders which relate to confiscation of property and monitoring of persons. The effect of such changes is to undo conventional approaches to sentencing by limiting the discretion of judges, and to shift subtly, yet undeniably, the focus from the convicted individual to the needs of the state. However, the reception of the courts to such tactics and the constitutional framework in place has tempered the potentially dramatic consequences of these changes.

\section{PRESUMPTIVE SENTENCES}

A presumptive minimum sentence was first introduced in Ireland by the Criminal Justice Act 1999 for drug-possession with intent to supply. While a mandatory life sentence for murder was already on the statute book, ${ }^{14}$ presumptive sentences were unprecedented. Section 4 of the 1999 Act provides that any person convicted of possessing drugs with a value of at least $€ 13,000$ with intent to supply shall receive a term of imprisonment for life or less, with ten years the minimum time to be served unless there are exceptional and specific circumstances which would make this unjust. The "exceptional circumstances" caveat permits the exercise

6 S Kilcommins, I O'Donnell, E O'Sullivan and B Vaughan, Crime, Punishment and the Search for Order in Ireland (Dublin: Institute of Public Administration, 2004), p. 145.

$7 \quad$ R v Williscroft [1975] VR 292 at 300.

8 See United States Sentencing Commission, Guidelines Manual (November 2006), §3E1.1. Moreover, in England and Wales the Sentencing Guidelines Council may issue guidelines under s. 170 of the Criminal Justice Act 2003.

9 People (DPP) v Tiernan [1988] IR 250.

10 T O’Malley, "Principled discretion: towards the development of a sentencing canon" (2001) 7:3 Bar Review 135.

11 State (Healy) v Donoghue [1976] IR 325 at 353.

12 T O'Malley, Sentencing Law and Practice 2nd edn (Dublin: Thomson Round Hall, 2006). See, e.g. Cox v Ireland [1992] 2 IR 503 at 524; People (DPP) v $M$ [1994] 2 ILRM 541 at 547; DPP v WC [1994] 1 ILRM 321 at 325; People (DPP) v McCormack [2000] 4 IR 356 at 359.

13 Rock v Ireland [1997] 3 IR 484 at 500.

14 Criminal Justice Act 1990, s. 2. 
of the court's discretion in certain instances, thereby insulating the provisions from constitutional challenge on the basis that the sentence imposed was disproportionate. ${ }^{15}$

The prescribed maximum and minimum sentences are "clear and definite guidance"16 which should only be departed from for good reason, 17 and the "very draconian penalties" were seen to reflect the legislature's view on the gravity of such offences. ${ }^{18}$ It has become apparent that the exceptional circumstances caveat has been applied in the majority of cases, ${ }^{19}$ where factors such as the accused's minor role as a courier, ${ }^{20}$ poor health, ${ }^{21}$ psychiatric history, ${ }^{22}$ limited intellectual capacity, the effect of remand imprisonment in a foreign country, co-operation with the police, ${ }^{23}$ and successful progress in a drug rehabilitation programme ${ }^{24}$ have been taken into account. ${ }^{25}$ Nevertheless, the courts have not declined to impose a sentence above the minimum where the circumstances and severity of the offence, including the sophistication of drug dealing, ${ }^{26}$ the amount and value of the drugs, ${ }^{27}$ previous criminal career, and failure to cooperate with the police, ${ }^{28}$ necessitated such a response. Notwithstanding this, the popular and political perception is that the tenyear sentence in the Criminal Justice Act 1999 is circumvented frequently by overly lenient judges ${ }^{29}$ who are criticised for failing to act "in the spirit of the legislation". 30

Since the 1999 Act, the presumptive sentence, a "revolutionary alteration superimposed on the conventional principles of sentencing", 31 has transfixed the Irish legislature as an apposite means of dealing with serious criminality. The Criminal Justice Act 2006 provides, inter alia, that the offender need not know the value of the drugs; ${ }^{32}$ it extends the presumptive minimum sentence to cover drugs importation ${ }^{33}$ and firearms offences, ${ }^{34}$ and imposes a mandatory minimum sentence of ten years for a second drug offence. ${ }^{35}$ In addition, the Criminal Justice Act 2007 introduces a type of "mandatory" sentence for

15 O’Malley, Sentencing Law and Practice (2000), p. 102.

16 People (DPP) v Botha [2004] 2 IR 375 at 384.

17 People (DPP) v Heffernan, unreported, Court of Criminal Appeal, 10 October 2002 per Hardiman J.

18 DPP v Henry, unreported, Court of Criminal Appeal, 15 May 2002.

19 Research carried out for the Department of Justice on drug supply trials from November 1999 to May 2001 indicates that, of the 55 cases studied, the presumptive minimum sentence was imposed in only three instances. P McEvoy, Research for the Department of Justice on the Criteria applied by the Courts in Sentencing under s. $15 A$ of the Misuse of Drugs Act 1977 (as amended) (15 February 2005), p. 8.

20 Botha [2004] 2 IR 375.

21 Ibid. Also People (DPP) v Vardacardis, unreported, Court of Criminal Appeal, 20 January 2003.

22 People (DPP) v Benjamin, unreported, Court of Criminal Appeal, 14 January 2002.

23 People (DPP) v Alexiou [2003] 3 IR 513 at 523.

24 People (DPP) v McGinty, unreported, Court of Criminal Appeal, 3 April 2006.

25 Indeed, suspended sentences have been imposed, such as in Alexiou [2003] 3 IR 513 and McGinty, unreported, Court of Criminal Appeal, 3 April 2006.

26 People (DPP) v Byrne [2003] 4 IR 423.

27 DPP v Long, unreported, Court of Criminal Appeal, 7 April 2006.

28 People (DPP) v Ducque, unreported, Court of Criminal Appeal, 15 July 2005; People (DPP) v McDonald, unreported, Dublin Circuit Criminal Court, 8 June 2005.

29 "Mandatory drug offence terms rarely imposed", Irish Times, 7 March 2006, p. 6.

30 Dáil Debates, 28 November 2006, vol. 628, col. 905 per Mr Kelleher.

31 DPP v Dermody, unreported, Court of Criminal Appeal, 21 December 2006.

32 S. $82(3)$.

33 S. 86.

34 Criminal Justice Act 2006, ss. 42, 57-60. The exceptional circumstances caveat also applies.

35 S. $4(d)$. 
second offences such as murder, false imprisonment, ${ }^{36}$ firearms offences, ${ }^{37}$ aggravated burglary, ${ }^{38}$ and drug trafficking. ${ }^{39}$ Nevertheless, subs. (3), which was inserted as the 2007 Bill progressed through the Irish legislature, states that such a sentence shall not be imposed where it would be disproportionate in all the circumstances of the case. This may safeguard the "two strikes" provision in the 2007 Act from challenge on the ground that it limits unduly the constitutional right to proportionality in sentencing, ${ }^{40}$ a challenge which, if successful, would render the provision invalid. ${ }^{41}$ This encapsulates the tension between the legislature's urge to limit proportionality and judicial discretion and the constitutional framework which compromises and mitigates this aim.

\section{Prosecution REFERRAL OF SENTENCE}

Further encroachment on courts' sentencing remit is evinced in the ability of the Director of Public Prosecutions (DPP) to refer unduly lenient sentences for review to the Court of Criminal Appeal under s. 2 of the Criminal Justice Act 1993. This measure, modelled on s. 36 of the Criminal Justice Act 1988 in England and Wales, ${ }^{42}$ was prompted by a number of controversial cases in which the sentence handed down was deemed by political and popular opinion to be inconsistent with the gravity of the offence. ${ }^{43}$

As the court in People (DPP) v Egan emphasised, the DPP's power "trenches upon the general right of a convicted person to presume that the sentence he receives from the trial judge is final unless he appeals it himself"; 44 thus certain criteria delineated by the courts limit this power. The DPP bears the onus of proof to demonstrate that the sentence is unduly lenient, ${ }^{45}$ and considerable weight should be given to the reasons of the trial judge for imposing the sentence, given that the judge "receives the evidence at first hand". 46 The

36 Non-Fatal Offences Against the Person Act 1997, s. 15.

37 Firearms Acts 1925-1964.

38 Criminal Justice (Theft and Fraud Offences) Act 2001, s. 13.

39 Criminal Justice Act 1994, s. 3(1). The precursor for such a punitive measure, which impacts considerably on judicial discretion and may disregard the individual characteristics of the accused, is evident in "three strikes" provisions in American states which impose an automatic life sentence on persons convicted of a third felony. California's "three strikes" laws were upheld in Ewing v California (2003) 538 US 11, where a 5:4 majority of the Supreme Court found that a sentence of 25 years to life for the felony theft of golf clubs did not violate the US Constitution's Eighth Amendment prohibition of cruel and unusual punishment.

40 Before the Irish President signed the Bill into law on 9 May 2007, she convened a meeting of the Council of State to determine if the Bill should be referred to the Supreme Court for consideration but decided not to do so. Art. 26 of the Constitution allows a Bill to be referred to the Supreme Court to determine its compatibility with the Constitution, and, according to the terms of Art. 34.3, approval by the Supreme Court insulates that provision from future challenge. See "President McAleese signs Criminal Justice Bill into law", Irish Times, 10 May 2007, p. 1.

41 Art. 15.4.2.

42 S. 36 provides that if it appears to the Attorney General that the sentence of a person in a proceeding in the Crown Court is unduly lenient, and the offence is triable only on indictment, he or she may refer the case to the Court of Appeal for review of the sentence. The Court of Appeal may quash the sentence and pass such sentence as it deems appropriate.

43 The first of these cases was People (DPP) v WC [1994] 1 ILRM 321, which involved a nine-year suspended sentence for a guilty plea to a rape charge. The victim renounced her anonymity to express her belief that the sentence imposed was too lenient. See T O’Malley, "Prosecution appeals against sentence" (1993) Irish Law Times 121.

44 People (DPP) v Egan [2001] 2 ILRM 299 at 308, following People (DPP) v Connolly, unreported, Court of Criminal Appeal, 25 November 1996.

45 People (DPP) v Byrne [1995] 1 ILRM 279 at 287.

46 Ibid. at 287. See T O’Malley, “The first prosecution appeal against sentence” (1994) 4 Irish Criminal Law Journal 192. 
intervention of the appeal court is warranted only if there is "a clear divergence by the court of trial from the norm . . . caused by an obvious error in principle". ${ }^{47}$ Though the strengthening of the prosecution's power evinces a perceptible shift in the traditional balance between the state and the accused and betrays the desire of the legislature to limit judicial autonomy, the strict rules in place offset the effects on this provision on judicial discretion. Moreover, although referral appears to bear repercussions for the constitutional right against double jeopardy, ${ }^{48}$ this line of argument was rejected by the Supreme Court in People (DPP) v Heeney, ${ }^{49}$ following (although not citing) the majority of the US Supreme Court in United States $\mathrm{v}$ DiFrancesco. ${ }^{50}$

\section{ANCILLARY POST-CONVICTION ORDERS}

A number of legislative provisions allow for post-conviction orders to be imposed, concerning property forfeiture and the monitoring of prisoners upon release.

Property may be confiscated after an individual has been convicted of certain crimes, according to the terms of the Criminal Justice Act 1994. Section 4 (as amended) requires a court to consider imposing a confiscation order where the offender has been convicted on indictment for a drug-trafficking offence and, if the court determines on the balance of probabilities that the offender has benefited from drug trafficking, it must make a confiscation order requiring the offender to pay the value of the proceeds of the criminality. ${ }^{51}$ There is a statutory presumption that any property received by the respondent in the six years prior to conviction constitutes the proceeds of drug trafficking. ${ }^{52}$ Similarly, s. 9 provides that a confiscation order may be made requiring a convicted person who has benefited from an offence other than drug trafficking to pay the value of the property so obtained. This is not a mandatory order, but may be imposed by the court upon application by the DPP.

A post-conviction requirement for sexual offenders in particular is contained in Pt 2 of the Sex Offenders Act 2001, which imposes a duty on a convicted sex offender to notify the Gardaí of name, address and any change thereof. ${ }^{53}$ Akin to this, Pt 9 of the Criminal Justice Act 2006 requires police notification for persons convicted and imprisoned for drug trafficking. Such an offender must inform the police within seven days of conviction of any names or nicknames and home address, ${ }^{54}$ after release must inform them of matters such

47 People (DPP) v McCormack [2000] 4 IR 356 at 359.

48 Art. 38.1 of the Irish Constitution.

49 People (DPP) v Heeney [2001] 1 IR 736, at 739-40.

50 United States v DiFrancesco (1980) 449 US 117.

51 In People (DPP) v Gilligan, unreported, Special Criminal Court, 22 March 2002, O'Donovan J stated that such a determination involved five matters: the cost to the plaintiff of purchasing drugs; the amount of drugs involved in the plaintiff's drug-trafficking activities; the expense of the shipment, sale and distribution of such drugs; the consideration received by the plaintiff when disposing of those drugs; and the net profit accruing to the plaintiff as a result of his drug-trafficking activities. Although the Supreme Court later held that the Special Criminal Court did not have jurisdiction to impose confiscation orders in Gilligan v Special Criminal Court, unreported, Supreme Court, 21 December 2005, para. 6.3, it is useful to see the factors that were considered by the trial court.

52 Criminal Justice Act 1994, s. 5(4)(ii). The Irish Law Reform Commission recommended the adoption of such a presumption. Law Reform Commission, Report on the Confiscation of the Proceeds of Crime (LRC 35-1991), p. 75. A similar provision in s. 3(2) of the Proceeds of Crime (Scotland) Act 1995 was ultimately found to be ECHRcompliant in McIntosh, Petitioner (2001) SC (PC) 89, while, in R v Benjafield [2003] 1 AC 1099, the House of Lords held that statutory assumptions in s. 72AA of the Criminal Justice Act 1988 and s. 4(3) of the Drug Trafficking Act 1994 were not disproportionate so as to breach Convention rights.

53 A register of convicted sex offenders was first introduced in the United States in the early 1990s. The Jacob Wetterling Crimes against Children and Sexually Violent Offender Registration Act 1994 required all states in the US to implement a sex offenders' register.

54 Criminal Justice Act 2006, s. 92(1). 
any change of address, ${ }^{55}$ and of any intention to leave the state. ${ }^{56} \mathrm{~A}$ comparable development is the inclusion of monitoring orders in s. 26(2) of the Criminal Justice Act 2007, for persons convicted of certain offences, including murder, false imprisonment, ${ }^{57}$ firearms offences, ${ }^{58}$ drug trafficking, ${ }^{59}$ and organised crime offences. ${ }^{60}$ The order, which lasts for at most seven years, requires the individual to notify in writing a police inspector of his or her address and any proposed absence from there for more than seven days. Failure to comply with either provision is an offence. ${ }^{61}$

These post-conviction ancillary orders potentially affect the right to proportionality in sentencing, by the imposition of an order supplementary to a term of imprisonment. However, when confiscation was challenged in Gilligan v Special Criminal Court on the basis that it constituted a de facto penalty imposed after a criminal procedure, ${ }^{62}$ this argument was rejected by the High Court, where McCracken J stressed that the relevant section does not purport to create a criminal charge, nor does it require the court to find that the person committed any offence other than that for which he or she was convicted. The making of an order did not involve the imposition of a punishment ${ }^{63}$ but rather sought to recover the value of the benefits gained through drug trafficking. ${ }^{64}$ McCracken J stressed that the amount to be recovered is limited to the amount of benefit received by the defendant and also by the defendant's means, so that the defendant cannot be ordered to make a payment without the means to do so, in contrast to financial penalties imposed for criminal offences which are absolute, irrespective of the defendant's resources. Moreover, the payment of the amount benefited from drug trafficking does not absolve the individual from liability for the offence. Thus, the courts found that the confiscation order did not engage or offend the right to proportionality.

As regards the constraining of the court's discretion, s. 4 of the Criminal Justice Act 1994 (as amended) imposes a mandatory requirement on the court to consider a confiscation order for drug-trafficking offences and so seems to impinge on judicial choice. As initially enacted, s. 4 required the court to consider a confiscation order only where the DPP entered an application expressing suspicion that the accused had benefited from the sale and supply of drugs. The subsequent amendment by the 1999 Act has not been challenged nor would it be found to impinge unjustifiably on judicial independence in sentencing, following Deaton v Attorney General which permits mandatory sentences but limits any choice in determining sentence from a selection to the judiciary. ${ }^{65}$

Whether notification requirements affect the right to proportionality adversely is also unlikely, given extant constitutional jurisprudence. The constitutionality of Pt 2 of the 2001 Act was unsuccessfully challenged in Enright v Ireland, where Geoghegan J stressed that the registration requirement does not constitute a penalty ${ }^{66}$ and is a proportionate measure to

55 S. 92.

56 S. $92(3)$ and (4).

57 Non-Fatal Offences Against the Person Act 1997, s. 15.

58 Firearms Acts 1925-1964.

59 Criminal Justice Act 1994, s. 3.

60 Criminal Justice Act 2006, ss. 71-3.

61 S. 94 and s. 25(16).

62 Gilligan v Special Criminal Court, unreported, High Court, 8 November 2002.

63 Murphy v GM [2001] 4 IR 113; Gilligan v Criminal Assets Bureau [1998] 3 IR 185.

64 Gilligan, unreported, High Court, 8 November 2002.

65 Deaton v Attorney General [1963] IR 170 at 182.

66 Enright $\mathrm{v}$ Ireland [2003] 2 IR 321 at 337. A comparable decision was reached in the context of the ECHR in Ibbotson $\mathrm{v}$ UK (1999) 27 EHRR (CD) 332. 
protect the rights of other citizens. ${ }^{67}$ The notification requirements in Pt 9 of the 2006 Act and Pt 2 of the Sex Offenders Act 2001 are comparable, and indeed, as Garland notes, governments are on a "war footing" with respect to drug trafficking and sex offending, ${ }^{68}$ explaining why similar approaches are adopted in both contexts. Therefore, it seems that the imposition of notification requirements under the 2006 legislation similarly is not an additional punishment for the accused, nor does it constitute a disproportionate response to the issue of drug trafficking, given that the effects on the rights of the individual in question are minor.

\section{Explaining the changes}

Various theoretical insights are relevant in assessing these post-conviction amendments, and in unpicking the often divergent motivations of the legislature and the judiciary in Ireland. Essentially, the Irish legislature seems to be driven by a risk averse and punitive logic, which sees crime control as not only an overarching aim of but as the superior value in the criminal justice system. Conversely, while the courts sometimes acquiesce in the objectives of Parliament, in general they are motivated by contrasting norms which favour process and individual liberty over consequentialist demands of crime control.

The classic work of Herbert Packer on two models of the criminal process, the criminal control model and the due process model, is valuable in conceptualising the ideological stimuli of the judicial and legislative arms of the Irish state. ${ }^{69}$ Whereas the former is an instrumental model which focuses on the effective control of crime, the latter emphasises the potential for abuse in the criminal justice process and therefore advocates a series of rights which protect the individual against the state. Although the due process model recognises the need for crime control, it elevates the protection of the individual so as to ensure that rights are not displaced by the desire to tackle crime ${ }^{70}$ and, in contrast, the crime control model favours the suppression of crime and the protection of the public. ${ }^{71}$

Packer argued that the validating authority of the crime control model is proximately administrative and ultimately legislative whereas the due process model's validating authority is judicial. ${ }^{72}$ And, indeed, in Ireland the crime control model represents the ideological basis for contemporary political discourse on crime, whereas due process norms provide the impetus for judicial rejection of some such tactics. The prevailing attitude in the political sphere is that the Irish justice system is unjustifiably entrenched in the due process paradigm, and pays scant regard to the imperatives of crime control. The former Minister for Justice noted "that the balance has shifted too far in favour of the accused" 73 - a sentiment echoed by senior police figures ${ }^{74}$ - which is seen to warrant the "rebalancing" of the system. ${ }^{75}$

67 Enright [2003] 2 IR 321 at 343.

68 D Garland, The Culture of Control: Crime and social order in contemporary society (Oxford: OUP, 2001), p. 172.

69 H Packer, The Limits of the Criminal Sanction (California: Stanford University Press, 1968). See E Campbell, "Decline of due process in the Irish justice system: beyond the culture of control?" (2006) 6 Hibernian LJ 125.

70 Packer, The Limits of the Criminal Sanction (n. 69 above), p. 164.

71 Ibid., p. 158.

72 Ibid., p. 173.

73 Dáil Debates, 15 February 2005, vol. 597, col. 1276 per Minister for Justice, Mr McDowell.

74 President of the Association of Garda Sergeants and Inspectors, "Submission to the Joint Committee on Justice, Equality, Defence, and Women's Rights", 8 December 2003; "Garda chief warns on court "imbalance", Irish Times, 23 March 2005, p. 4.

75 Department of Justice, Equality and Law Reform, "Rebalancing Criminal Justice - Remarks by Tanaiste in Limerick" (speech), 20 October 2006; Balance in the Criminal Law Review Group (BCLRG), Final Report of the Balance in the Criminal Law Review Group (Dublin: Stationery Office, 15 March 2007), p. 3; and Dáil Debates, 15 February 2005, vol. 597, col. 1276 per Minister for Justice. 
In addition to the imperative of crime control, recent legislative developments at the post-trial stage of the criminal process belie the influence of the new penology - described by Feeley and Simon as an emerging paradigm with revised discourses, objectives and techniques $^{76}$ - which focuses on probability and risk and regards offenders as aggregates rather than individuals. ${ }^{77}$ The focus is less on the responsibility, culpability and treatment of offenders, but rather on managerial techniques to identify, categorise and organise groups according to dangerousness and risk. ${ }^{78}$ The influence of the new penology is particularly evident in the scheme of presumptive sentences in which the legislature seeks to subsume individual characteristics to the classification of offenders into groups. ${ }^{79}$ Moreover, like the sex offenders' register which was conceived as a "tool for risk management" 80 and a means of control, ${ }^{81}$ the notification requirements in the 2006 Act focus on the control of released drug traffickers, rather than on rehabilitation or reform. Such an approach evinces a growing belief that particular types of criminal are not capable of reform, but rather retain the potential to commit further criminal behaviour and so should be continuously surveyed. Nevertheless, the approval by the courts of these tactics established their compliance with domestic human rights norms and set them beyond constitutional challenge in future.

Building on the notion of a "new penology", Garland characterised certain criminal justice measures as "adaptive responses" of the state to a perceived crisis in crime control. ${ }^{82}$ While he proffered examples in the US and UK, including improved caseload management, systematic information-gathering, the development of a managerialist ethos and an increased stress on incapacitation, the post-conviction orders imposed in Ireland also fit into this schema, given that they provide the state with a supplementary means of dealing with criminality beyond the confines of the traditional criminal justice realm. Indeed, the judiciary has not displayed the same circumspection towards such orders, as in the context of presumptive sentences and prosecution sentence referrals, and has acquiesced in this approach to combating serious crime.

In addition to conceptualising these measures in an "adaptive" sense, they can be seen to possess a more straightforward instrumental worth. Presumptive sentences are of instrumental value in terms of incapacitation, given that they may seek to remove offenders from society for a longer period than is normally imposed by the courts. Moreover, it was argued (rather optimistically, it must be added) that the presumptive sentence in the Criminal Justice Act 1999 would "eradicate" the illegal drugs trade, 83 while the presumptive sentence for firearms offences in the 2006 Act would provide a "substantial deterrent". 84 Furthermore, the Minister for Justice in 2005 expressed his belief that the presumptive sentence for drug possession has a benefit in terms of guilty pleas and the co-operation received by the Garda Síochána from the offender in the hope of having the sentence

76 M Feeley and J Simon, "The new penology: notes on the emerging strategy of corrections and its implications" (1992) 30 Criminology 449; and M Feeley and J Simon, "Actuarial justice: the emerging criminal law" in D Nelken (ed.), The Futures of Criminology (London: Sage, 1994), p. 185.

77 Feeley and Simon, "The new penology" (n. 76 above), pp. 449-50.

78 Ibid., p. 452.

79 Ibid., p. 461.

80 C White, "Controlling sex offenders: raising critical questions about the Sex Offenders Bill 2000" (2001) Irish Journal of Family Law 8, 11.

81 S Walsh, "Doing justice: recent developments in sentencing and rehabilitation of sex offenders" (2002) 12 Irish Criminal Law Journal 6.

82 Garland, The Culture of Control (n. 69 above), p. 113.

83 Dáil Debates, 21 April 1999, vol. 503, col. 838 per Minister for Justice, Mr O’Donoghue.

84 Department of Justice, Equality and Law Reform, "Minister announces 7\% decrease in provisional headline crime figures" (press release), 26 October 2004. 
reduced. ${ }^{85}$ Notification requirements and monitoring orders also fulfil practical purposes. By monitoring certain groups of offenders, the state seeks to prevent the commission of crime, or if this is not possible, to ease its task in investigation by ensuring that the police are furnished with sufficient information to track the movements of ex-convicts.

Presumptive sentences and post-conviction orders serve a symbolic end, indicating society's view of particular offences. As Garland notes, the symbolic, expressive and communicative aspects of penal sanctions seem to have become more significant in recent years, and " $[\mathrm{t}]$ he emotional temperature of policy-making has shifted from cool to hot". 86 As sentencing involves a public statement about an offender and an offence, ${ }^{87}$ expressive sanctions may relieve tension and serve as a cathartic and gratifying moment of unity in the face of crime. ${ }^{88}$ Indeed, the "unequivocal" message that the original presumptive sentence in the 1999 Act would send to criminals was emphasised in Parliament, ${ }^{89}$ as was its capacity to demonstrate society's abhorrence of the trafficking of drugs. ${ }^{90}$ By prescribing a minimum sentence, the legislature expresses its disapprobation of those crimes regarded as most pernicious to society.

Similarly, the enactment of a sex offender register may be viewed as a political response to mollify a fearful public, given that prior to the Bill's passing the Department of Justice conceded that the police in effect already maintained a register of all persons convicted of sexual offences. ${ }^{91}$ The additional obligation posed on sex offenders to inform the Gardai of a change of address is of dubious effect in preventing the perpetration of a crime. Nevertheless, the efficacy of the legislation was not questioned, politicians seemed convinced of its importance, ${ }^{92}$ and so this statute was enacted to alleviate the fears of the public vis-à-vis predatory sex offenders. A measure such as a register is designed to reassure the public in a decisive manner, regardless of its substantive effectiveness.

The introduction of presumptive sentences and post-conviction orders demonstrates a growing emphasis on the crime rather than on the particular offender. This focus on the crime holds the potential to result in an abstract generalised judgment, which leads to bias for more punitive sentences on protective, symbolic and condemnatory grounds. ${ }^{93}$ There is a drift away from seeing proportionality as central to sentencing and an entrenchment of scepticism towards the judiciary, encapsulated in the ability of the prosecution to refer unduly lenient sentences to an appellate court. However, various legal and attitudinal factors in place safeguard the freedom of choice of the courts in sentencing, and temper the punitive consequences for the offender.

85 Minister for Justice, "Criminal Justice Bill 2004: ministerial presentation to the Joint Committee on Justice, Equality, Defence and Women's Rights”, 7 September 2005.

86 Garland, The Culture of Control (n. 69 above), pp. 10-11.

87 A Ashworth, Sentencing and Public Policy (London: Weidenfeld \& Nicolson, 1983), p. 111.

88 D Garland, "The culture of high crime societies: some preconditions of recent 'law and order' policies" (2000) 40 British Journal of Criminology 347, 350.

89 Dáil Debates, 21 April 1999, vol. 503, col. 837 per Minister for Justice, Mr O’Donoghue. Also Dáil Debates, 1 July 1998, vol. 493, col. 883 per Minister for Justice, Mr O’Donoghue.

90 Dáil Debates, 21 April 1999, vol. 503, col. 787 per Minister for Justice, Mr O’Donoghue.

91 Department of Justice, Equality and Law Reform, The Law on Sexual Offences: A discussion paper (Dublin: Stationery Office, 1998), p. 79.

92 Dáil Debates, 20 Nov 2001, vol. 544, col. 836; also 3 Oct 2001, vol. 541, col. 226.

93 F Zimring, G Hawkins and S Kamin, Punishment and Democracy: Three strikes and you're out in California (New York: OUP, 2000), pp. 199-200. 


\section{The judicial bulwark}

The constitutional structure in place in Ireland, coupled with the underlying ideology of judicial decisions, has mitigated the effects of legislative incursions on conventional approaches to sentencing. In contrast to Parliament, which seems increasingly propelled by crime control as a normative value, the High Court has stated that "the primary purpose [of the Constitution] in the field of fundamental rights is to protect them from unjust laws enacted by the legislature", 94 and by interpreting the Constitution in a way that may be characterised as rights-enforcing, the courts are pitted against more results-oriented and consequentialist politicians. This is exemplified by the comment of Denham $\mathrm{J}$ in the Supreme Court that "the applicant's right to due process is a right inherent in the concept of justice, which is at the core of the Constitution". 95

Under the Irish Constitution, any legislative measure that is found to conflict with the Constitution is invalidated, ${ }^{96}$ in contrast to the scheme in the UK where the Human Rights Act 1998 permits the courts to make merely a declaration of incompatibility. ${ }^{97}$ Any sentencing provision which could impact on the constitutional right to proportionality runs the risk of being deemed invalid, and this is the reason for the inclusion of the "exceptional circumstances" provision in the Criminal Justice Acts 1999-2007. Therefore, while the motivating aims of the legislature (including deterrence, the conveyance of disapproval and the incapacitation of criminals) in devising such provisions have the potential to undermine the determining principle of proportionality in sentencing, the exceptional circumstances caveat has permitted the courts to circumvent the punitive intention of the legislature to a certain extent and to withstand the drift towards a crime control model of criminal justice, by ensuring that the rights and personal circumstances of the offender are adequately considered.

In addition to the concept of proportionality in sentencing, the broader notion of independence counteracts the attempts of the legislature to intervene in judicial matters. Independence in all aspects of the courts' duties is constitutionally enshrined, ${ }^{98}$ and has been described as the most significant aspect of the separation of powers in Ireland. ${ }^{99}$

While the dynamic between the judiciary and the legislature is a vital element of democracy, recent years have seen increased criticism of the courts by politicians, such as when the Minister for Justice stressed to the judiciary that the exceptional and specific sentencing derogation should only be used in a "minority of cases", that the judiciary should be influenced by the "political consensus" that "[d]rugs have such a dramatic effect on the quality of life in our society, [that] a prisoner-focused sentencing policy . . . is mistaken when it goes too far", ${ }^{100}$ that "the judicial arm of the State as well must play its part in the suppression of gangland violence". ${ }^{101}$ Further evidence of diminishing legislative deference to the courts lies in the action of the Government Deputy Chief Whip

94 PH v Murpby [1987] IR 621.

95 People (DPP) v Gilligan, unreported, Supreme Court, 23 November 2005.

96 However, a presumption of constitutionality applies in the interpretation of legislation by the courts, and an Act will be seen as valid if it is possible to construe it in accordance with the Constitution (see Pigs Marketing Board v Donnelly [1939] IR 413; Buckley v Attorney General [1950] IR 67; East Donegal Co-Operative Livestock Mart Ltd v Attorney General [1970] IR 317).

97 S. 4.

98 Art. 35.

99 D Gwynn Morgan, Constitutional Law of Ireland: The law of the executive, legislature, and judicature (Dublin: Round Hall Press, 1985), p. 188.

100 Dáil Debates, 24 May 2006, vol. 620, col. 502 per Minister for Justice, Mr McDowell.

101 See "McDowell criticises bail law application", Irish Times, 15 December 2006, p. 8. 
in writing to the President of the High Court about the high proportion of drug dealers "escaping" the ten-year sentence. ${ }^{102}$

In response, the Court of Criminal Appeal, in DPP $\mathrm{v}$ Dermody, ${ }^{103}$ claimed it paid such political commentary "no attention whatever" and that the sentence has been "reasonably successful in its operation". ${ }^{104}$ Nevertheless, the associated coolness between the judiciary and the Minister for Justice culminated in a boycott of a Christmas party held by the Department of Justice by the vast majority of senior judges, ${ }^{105}$ indicating their distaste for political intervention in what are construed as strictly judicial issues. Although criticism of the court, or "even emphatic disagreement", has been seen as crucial in society given the right to freedom of expression, ${ }^{106}$ this increasing political intervention cannot amount to anything more than posturing, given the constitutional rules in place.

In addition to the courts' opposition to a model of justice which favours crime control at the expense of due process, the Constitution and ingrained judicial ideologies prelude the adoption of risk-focused penologies which view offenders as aggregates. The significant number of cases in which the presumptive minimum sentence has not been imposed underlines the power of the courts to withstand actuarial rationales, by drawing on the constitutional standard of proportionality. Whereas Feeley and Simon lament the capitulation of the US courts in the actuarial approach, ${ }^{107}$ the Irish courts seem to withstand the managerial and risk-oriented approach of the legislature. ${ }^{108}$

While the judiciary seems to temper the punitive legislative trend at the post-trial stage of the criminal process, in fact, there is a predilection for the use of imprisonment, in particular on behalf of the lower level courts. The numbers of prisoners on remand has been "increasing steadily": 109 while there were 322 prisoners on remand on a given day in 2000, the number in 2001 was 458, while the increase continued to 488 on a particular day in 2003 and 519 in 2006. ${ }^{110}$ Furthermore, the number of committals to prison has risen from 10,658 committals in 2005 to 12,157 in 2006, and a considerable cohort of these comprises short sentences. In 2005, from a total of 5088 sentences, 1962 were sentences of less than three months and a further 1020 between three and six months; while, in 2006, a total of 5802 sentences included 2253 sentences of less than three months and 1220 between three and six months. ${ }^{111}$ This substantiates O'Donnell's claim that there is "a strong orientation towards custody among Irish judges". 112 This preference for

102 “Courts pulled up for 'low' drug jail terms”, Irish Independent, 13 November 2006.

103 DPP v Dermody, unreported, Court of Criminal Appeal, 21 December 2006.

104 See McEvoy, Research for the Department of Justice (n. 19 above), p. 11.

105 See "Judges boycott McDowell reception over bail comments", Irish Times, 22 December 2006, p. 1.

106 State (DPP) v Walsh [1981] IR 412 at 421.

107 Feeley and Simon claim that US courts have used actuarial justice in preventative detention cases (Salernov US (1987) 481 US 739) and have sanctioned the use of profiles as a basis for detaining people. Feeley and Simon, "Actuarial justice" (n. 76 above), p. 180.

108 Feeley and Simon, "Actuarial justice" (n. 76 above), p. 180.

109 Irish Prison Service, Report 1999 and 2000 (Dublin: Irish Prison Service, 2000), p. 10.

110 Irish Prison Service, Annual Report 2003 (Dublin: Irish Prison Service, 2004), p. 20; Irish Prison Service, Annual Report 2006 (Dublin: Irish Prison Service, 2007) p. 16.

111 Irish Prison Service, Annual Report 2005 (Dublin: Irish Prison Service, 2006), p. 12; Irish Prison Service, Annual Report 2006 (n. 110 above), p. 14.

112 I O’Donnell, "Imprisonment and penal policy in Ireland" (2004) 43 Howard Journal 253, 257. 
imprisonment is further evidenced in the fact that almost as many individuals are imprisoned each year as are supervised in the community. ${ }^{113}$

Thus, characterising the judiciary as an impenetrable safeguard against legislative incursions on norms of proportionality and restraint in the imposition of punishment is unduly simplistic and neglects the punitive inclinations of some courts.

\section{Conclusion}

Alterations in the realm of sentencing in Ireland, and more generally at the post-conviction stage of the criminal process, are indicative of the shift in focus away from the interests of the individual towards the crime control-oriented needs of the state. Risk management and the control of offenders, either by incapacitative sentences or through post-conviction orders, have increased in significance. In addition, the expressive element of tactics such as presumptive minimum sentences must not be overlooked, given their ability to convey the disapprobation of policy makers and society in general. Moreover, the ability of the DPP to appeal unduly lenient sentences enhances the capabilities of the state and shifts the balance in its favour, while the imposition of confiscation orders exemplifies the adoption of novel and adaptive tactics by the state in a bid to undercut the profits accrued as a result of criminal behaviour.

Notwithstanding these considerable developments in the post-trial context, various factors ensure that the measures introduced by the legislature remain circumscribed. The judiciary's strident protection of its independence, coupled with its reluctance to provide sentencing guidelines, has allowed the flexible structure of sentencing in Ireland to be retained, thereby mitigating the more punitive tendencies of the legislature. This capacity of the judiciary to counterbalance the trend towards a crime control model of criminal justice is evident from the widespread application of the exceptional circumstances caveat to presumptive sentences. Similarly, whilst the DPP may request a review of unduly lenient sentences, the courts require the satisfaction of strict criteria before an appeal is entertained. Thus, the legislature's predilection for more punitive measures is tempered by the courts and by the enduring strength of the traditional structures and principles in place.

Increasing legislative intervention is evident in the post-trial realm, which impinges on the usual discretion accorded to judges. The growing desire of the legislature to intervene in the traditional role of the judiciary seems to be founded on a broader distrust of the judiciary, given its apparent "failure" to apply presumptive sentences, ${ }^{114}$ and the perception that the courts are unduly lenient, ${ }^{115}$ a perception which is demonstrably ill-founded given the sustained levels of imprisonment. However, it is evident that "potentially grave damage" could be caused to the administration of justice unless the public expectation that sentences be "coherent, rational and consistent" is met. ${ }^{116}$ One possible means of ensuring more

113 See Comptroller and Auditor General, The Probation and Welfare Service: Report on value for money examination (Dublin: Government of Ireland, 2004), p. 21 and M Seymour, Alternatives to Custody in Ireland (Dublin: Business in the Community and the Irish Penal Reform Trust, 2006), p. 6.

114 The Minister for Justice claimed that "the people of Ireland are strongly of the view that these penalties [for drugs offences] are appropriate”. Department of Justice, Equality and Law Reform, "Address by An Tanaiste to the Annual Delegate Conference of the Association of Garda Sergeants and Inspectors" (Press Release), 2 April 2007.

115 A recent police survey concluded that 82 per cent believed that the criminal justice system's treatment of offenders is too lenient, up from 74 per cent in 2002. P Kennedy and C Browne, Garda Public Attitudes Survey 2006 (Tipperary: Garda Research Unit, 2006), p. 51. A figure of 81 per cent was also recorded in an Irish Independent/IMS poll of 2002. See "Crime battle is lost", Irish Independent, 6 May 2002.

116 Dáil Debates, 22 March 2007, vol. 34, col. 383 per Minister for Justice, Mr McDowell. 
consistency and thereby increasing public confidence ${ }^{117}$ without impinging unjustifiably on judicial discretion would be to devise sentencing guidelines: as a system of objective guidance for sentencing judges; 118 or by the development of "guideline judgments" by the superior courts where a number of appeals concerning the same offence would be heard together and the judgment would indicate the approximate mid-point on the scale of severity and the factors that warrant movement from this point. ${ }^{119}$ Moreover, as Tonry has suggested, guidelines aim to achieve consistent treatment of comparable offenders and are scaled to offence severity, and therefore may in fact assist in proportionality in sentencing. ${ }^{120}$ The imposition of sentencing guidelines rather than presumptive sentences represents an apposite way of reconciling the conflicting demands of both legislative and judicial restraint in the post-trial stage of the criminal justice system.

117 A Ashworth and M Hough, "Sentencing and the climate of opinion" (1996) Criminal Law Review 776, 781; Law Reform Commission, Consultation Paper on Sentencing (Dublin: Law Reform Commission, 1993), pp. 61-2.

118 Working Group on the Jurisdiction of the Courts, The Criminal Jurisdiction of the Courts (Dublin: Courts Service, 2003), p. 20.

119 BCLRG, Final Report (n. 75 above), p. 227.

120 M Tonry, "Parochialism in US sentencing policy" (1999) 45 Crime and Delinquency 48, 59. 
